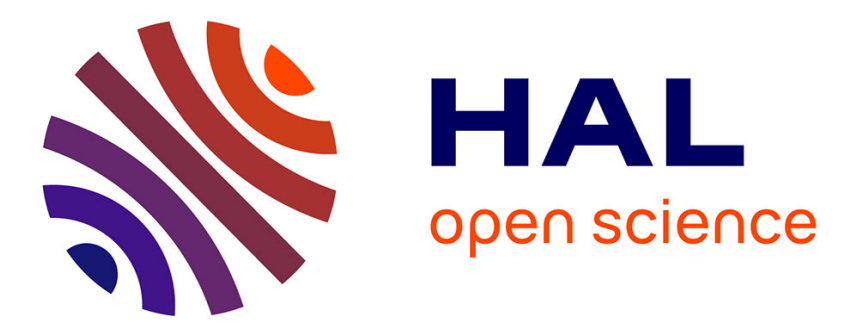

\title{
A Lab-Scale Alternative Interconnection Solution of Semiconductor Dice Compatible with Power Modules 3-D Integration
}

Ludovic Ménager, Maher Soueidan, Bruno Allard, Vincent Bley, Benoît Schlegel

\section{To cite this version:}

Ludovic Ménager, Maher Soueidan, Bruno Allard, Vincent Bley, Benoît Schlegel. A Lab-Scale Alternative Interconnection Solution of Semiconductor Dice Compatible with Power Modules 3-D Integration. IEEE Transactions on Power Electronics, 2010, 25 (7), pp.1667 - 1670. 10.1109/TPEL.2010.2041557. hal-00476271

\section{HAL Id: hal-00476271 \\ https://hal.science/hal-00476271}

Submitted on 25 Mar 2011

HAL is a multi-disciplinary open access archive for the deposit and dissemination of scientific research documents, whether they are published or not. The documents may come from teaching and research institutions in France or abroad, or from public or private research centers.
L'archive ouverte pluridisciplinaire HAL, est destinée au dépôt et à la diffusion de documents scientifiques de niveau recherche, publiés ou non, émanant des établissements d'enseignement et de recherche français ou étrangers, des laboratoires publics ou privés. 


\title{
Letters
}

\section{A Lab-Scale Alternative Interconnection Solution of Semiconductor Dice Compatible with Power Modules 3-D Integration}

\author{
Ludovic Ménager, Maher Soueidan, Bruno Allard, Vincent Bley, and Benoît Schlegel
}

\begin{abstract}
Increase in the power density of power modules requires an interconnection technology alternative to wire-bonding technology. Emerging interconnection technologies allow a 3-D packaging of power modules. A proposal of interconnection solution for the power semiconductor dice is presented here; it is based on copper microposts that are electroplated on topside of the die. The die with its microposts is then attached to a top direct-bonding copper (DBC) substrate using a copper/tin transient liquid phase technique. The assembly of the backside of the die to a bottom DBC substrate is processed concurrently using the same transient liquid phase technique. The benefits or limitations of the substrate on the assembly are not discussed in this letter. Manufacturing and electrical characterization of a power semiconductor die with the microposts interconnection is presented in detail.
\end{abstract}

Index Terms-3-D packaging, Electroplating, power density, semiconductor die, transient liquid phase bonding.

\section{INTRODUCTION}

$\mathbf{T}$ HE MOST common die-level interconnect technology in power modules is wire bonding. Maturity, flexibility, and low cost are main factors that explain the use of the wire-bonding technology plus recent improvement with respect to tin-less solder regulation or high temperature capability. However, wirebonding technology has electrical and thermomechanical limitations. A wire usually involves a parasitic inductance about $10 \mathrm{nH}$ [1]. This parasitic inductance induces over voltages at the switch level and is globally a limiting factor regarding the maximum switching frequency. It slows down the turn ON/OFF of the switch that induces an increase in commutation losses. It also contributes to the dynamic current unbalancing in parallelconnected dice [1]. From a thermal point of view, the heat flux dissipation is limited to one direction. In fact, the main thermal path is the backside of the dice. Finally, wire bonds are

Manuscript received October 8, 2009; revised November 27, 2009. Date of current version June 18, 2010. Recommended for publication by Associate Editor K. Sheng.

L. Ménager is with the INRETS, LTN Laboratory, Versailles F-78008, France (e-mail: ludovic.menager@inrets.fr).

M. Soueidan and B. Allard are with the Ampere Laboratory, Institut National des Sciences Appliquées (INSA) Lyon, Université de Lyon, CNRS UMR 5005, Villeurbanne F-69621, France (e-mail: maher.soueidan@insa-lyon.fr; bruno.allard@insa-lyon.fr).

V. Bley and B. Schlegel are with the Laplace Laboratory, Université de Toulouse and Université Paul Sabatier, CNRS, UMR 5213, Toulouse F-31062, France (e-mail: vincent.bley@laplace.univ-tlse.fr; benoit.schlegel@ laplace.univ-tlse.fr).

Digital Object Identifier 10.1109/TPEL.2010.2041557 subject to thermomechanical stresses when temperature cycling is installed. This leads to a wire-bond fatigue and eventually a failure [2].

Alternative interconnection technologies have been developed to overcome the latter shortcomings in wire-bonding technology, and that allow a 3-D packaging of power modules in a compact-stacked layer structure [3]-[5]. The proposed technologies can be divided into four categories: solder interconnection, interconnection by springs, pressure contact, and interconnection by electroplated metallizations. The advanced interconnection technologies permit a decrease in the values of parasitic inductance and electrical resistance. They also offer opportunities to improve the thermal management by an access to the topside of the dice. However, the 3-D interconnection technologies have drawbacks. Literature reports, robustness, and reliability limits the solder interconnection technologies particularly under repetitive thermal cycling, and moreover under higher ambient temperature [6]. In the interconnection by springs, the heat-flux dissipation of the dice is realized mainly by the backside because the springs have a high thermal resistance [4]. The manufacturing process of the spring-interconnection technology is complex and limits its acceptance. Concerning the pressure contact, the main problems are the complicated mechanical structure and assembly programs. Moreover, some of the pressure contact technologies still include wire bonds for low-power connection [7]. In the interconnection by electroplated metallizations, the major drawbacks are the stress problems at the solder level as the mechanical rigidity of the assembly is augmented [7]. Finally, few alternative technologies to wire bonding have bridge the gap to industrial process and market acceptance [8]-[9]. Most of them remain laboratory-scale experience.

This letter details the experience of an alternative laboratoryscale interconnection technology called microposts interconnection. Our aim is to realize a 3-D assembly, compatible with low-cost and high-volume manufacturing solutions; the microposts are grown in one step on a whole silicon-dice wafer, and both the top and bottom of the die are bonded at the same time. Furthermore, by providing a thermal path on both sides of the power die (whereas cooling is done on one side only with the current technology), this 3-D structure is suited to highpower devices. The technology issues are described in Section II. Section III shows the electrical characterization of the microposts interconnection and the results are discussed in Section IV. Conclusions and perspectives are given in Section V. 


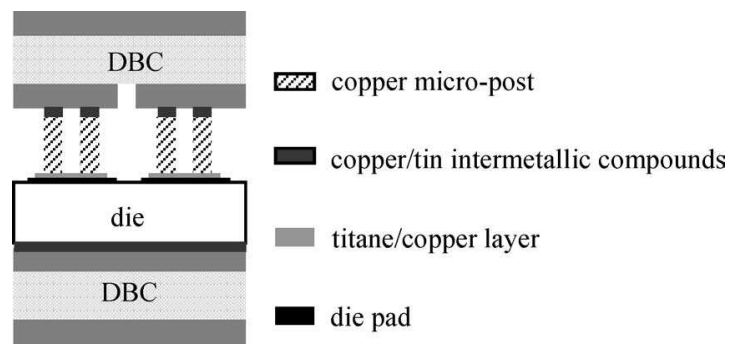

Fig. 1. Schematic of the proposed die interconnection using micro-posts.

TABLE I

BONDING MATERIAL FAMILIES WITH THEIR BONDING AND REMELTING TEMPERATURES [10]

\begin{tabular}{|c|c|c|}
\hline Material & $\begin{array}{c}\text { Bonding temperature } \\
\left({ }^{\circ} \mathrm{C}\right)\end{array}$ & $\begin{array}{c}\text { Remelting temperature } \\
\left({ }^{\circ} \mathrm{C}\right)\end{array}$ \\
\hline Nickel / tin & 300 & 400 \\
\hline Silver / indium & 175 & 880 \\
\hline Silver / tin & 250 & 600 \\
\hline Copper / indium & 180 & 307 \\
\hline Copper / tin & 280 & 415 \\
\hline Gold / indium & 200 & 495 \\
\hline Gold / tin & 450 & 900 \\
\hline
\end{tabular}

\section{Microposts InTERCONNECTION OVERVIEW}

The proposed interconnection is based on copper microposts that are electroplated on the topside of the die (see Fig. 1). The microposts have typically a square section in the range of $100 \mu \mathrm{m} \times 100 \mu \mathrm{m}$, up to $300 \mu \mathrm{m} \times 300 \mu \mathrm{m}$ (to keep a sufficient density) and a height in the range of $100 \mu \mathrm{m}$. The distance between two microposts is fixed to $300 \mu \mathrm{m}$ in the first step. Section dimension and postinterdistance are values to be optimized. Reducing section and increasing postdensity impact favorably the mechanical rigidity and the thermal performance so far but could degrade reliability perspectives. Copper presents a good tradeoff between sufficient electrical and thermal conductivities, cost, availability, and manufacturability. The microposts are realized by electroplating. Other plating methods like evaporation, sputtering, and electroless do not allow in achieving affordably thicknesses close to $100 \mu \mathrm{m}$ with large growth rate. Moreover, this plating method requires few equipments, and is thus low cost.

The die with its copper microposts is attached to the top direct-bonding copper (DBC) substrate by copper $(\mathrm{Cu}) / \mathrm{tin}(\mathrm{Sn})$ transient liquid phase (TLP) bonding step (see Fig. 1). The TLP bonding step uses a low-melting temperature metal (tin, indium, ... .) to bond two high melting temperature metals (nickel, copper, silver, gold, ... ) together [10]. During the TLP bonding that necessitates quite a high temperature, pressure, and time-sensitive procedure, the diffusion of the low-melting temperature metal in the high-melting temperature metals induces a formation of intermetallic compounds. The presence of intermetallic compounds permits to have a joint with a remelting temperature more important than its bonding temperature. Table I lists some TLP bonding material families with their bonding and remelting temperatures. The DBC substrate was selected for compatibility with the copper microposts. Other combinations may be considered but have not been tested so far.
The main interests of the proposed microposts interconnection are the elimination of a solder layer between the die pads and the interconnection on the one hand. On the other hand, the $\mathrm{Cu} / \mathrm{Sn}$ TLP bonding allows in achieving joints with a high remelting temperature above $300^{\circ} \mathrm{C}$, and so is a solution compatible so far with high temperature packaging [10]. The other advantages are the following. The small sizes of the microposts permit to create a matrix of contacts on a usual power die. It decreases the values of parasitic inductance and electrical resistance. From a thermal point of view, the microposts interconnection offers a thermal access on the topside of the die. The proportion of heat flux removal through this top connexion has not been yet measured but finite-element method simulations indicate a ratio of $20 \%-30 \%$ of the total heat flow (static operating conditions with COMSOL). It is then safe to consider a positive impact on the junction operating temperature of the die. The possibility to introduce a dielectric fluid and/or gel between the microposts will allow improving the heat flux dissipation from the topside of the die.

\section{MANufacturing AND Electrical Characterization OF THE MICROPOSTS INTERCONNECTION}

The different manufacturing steps to realize the microposts interconnection on a chip are presented in Fig. 2. Before the electroplating of the microposts, the die pads must be covered with a thin titane (Ti)/copper $(\mathrm{Cu})$ layer $(20 / 100 \mathrm{~nm}$, respectively) if the pads are ready for wire bonding or bump. Properly prepared pads for copper electroplating would suppress this primary preparation of the die. Titane is used as an adhesion layer and copper is employed as a conductive layer for the electroplating step. Before the deposition of the $\mathrm{Ti} / \mathrm{Cu}$ layer, a photolithography step isolates the die pads (photoresist thickness close to $2 \mu \mathrm{m}$ ). This photoresist will permit to remove the Ti/Cu layer around the die pads by lift-off after the electroplating of the microposts, and so to avoid the short circuit between the die pads.

A second masking step is performed prior to the electrolytic growth of the microposts using a dry film photoresist (Riston PM275 dry film photoresist [11]) mainly seen in the electronics industry to realize printed circuit boards. The dry film photoresist is composed of a photoresist sandwiched between a polyethylene protective foil and a polyester support. It offers some benefits such as a simple process, a remarkable robustness to the acid bath, a decrease in the edge beads on the substrate, and a low cost. The dry film photoresist has a thickness of $75 \mu \mathrm{m}$ and a nominal resolution of $50 \mu \mathrm{m}$. The process to realize the pattern in one layer of the Riston PM275 is the following. The die is heated at $70^{\circ} \mathrm{C}$ for $1 \mathrm{~min}$. This heating step allows improving the dry film photoresist adhesion on the die. The polyethylene foil is removed. The photoresist is deposited by lamination on the die $\left(100^{\circ} \mathrm{C}\right.$ and $0.3 \mathrm{MPa}$ pressure). It is then exposed to an UV source with an intensity between 12 and $15 \mathrm{~mW} / \mathrm{cm}^{2}$, and a wave length of $385 \mathrm{~nm}$, respectively. The exposure time is comprised between 5 and $7 \mathrm{~s}$, respectively. After lamination and exposure, the polyester support is peeled away. Finally, the photoresist is developed with a spray system 


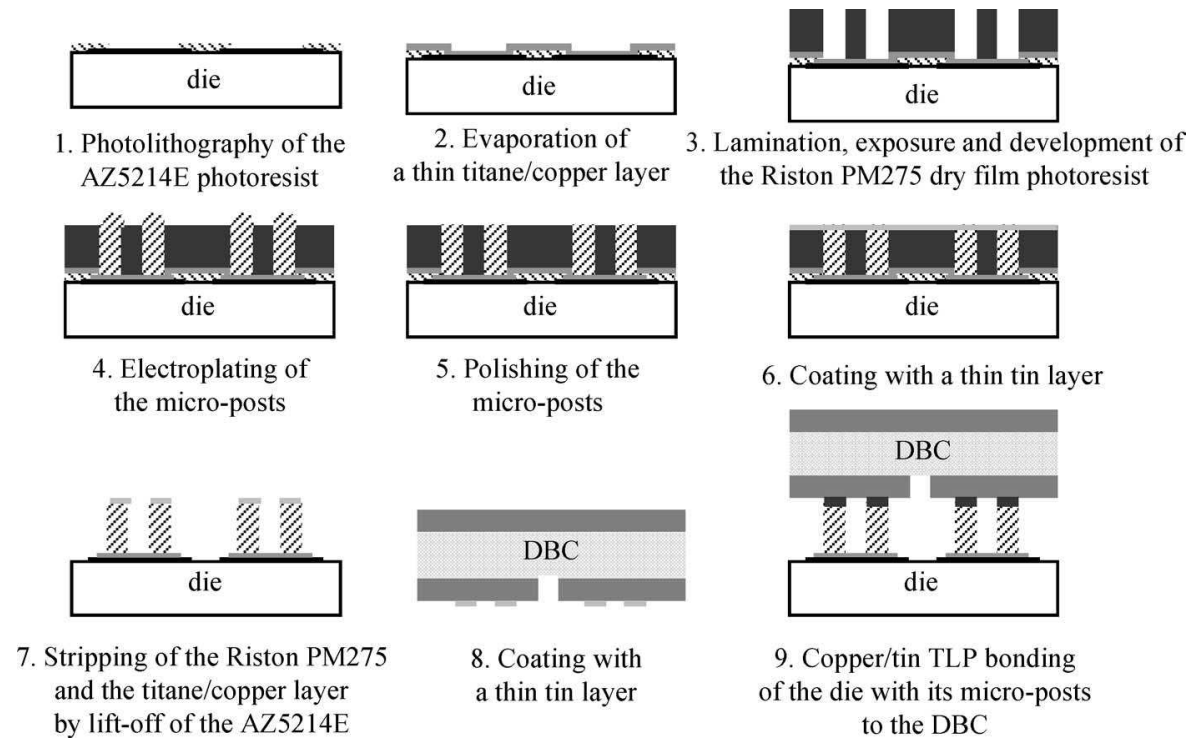

Fig. 2. Manufacturing process of the proposed interconnection.

in a sodium carbonate solution at $1 \%$ (5 g of sodium carbonate diluted in $500 \mathrm{~mL}$ of water) during $1 \mathrm{~min}$ and $30 \mathrm{~s}$ and with a processing temperature of $30^{\circ} \mathrm{C}$. The experimental electrolytic cell has horizontal electrodes. This configuration allows obtaining homogeneous microposts. The electrolytic bath is composed of pentahydrate copper sulphate $(220 \mathrm{~g} / \mathrm{L})$, sulphuric acid $(32 \mathrm{~mL} / \mathrm{L})$, hydrochloric acid $(0.2 \mathrm{~mL} / \mathrm{L})$, and brightener and leveler additives $(2 \mathrm{~mL} / \mathrm{L}$ of Rubin T200-A, $8 \mathrm{~mL} / \mathrm{L}$ of Rubin T200-G and $2 \mathrm{~mL} / \mathrm{L}$ of Rubin T200-E). Electroplating of the microposts is performed at ambient temperature with a typical current density of $10 \mathrm{~mA} / \mathrm{cm}^{2}$. The experimental growth rate of the microposts is linear and close to $11 \mu \mathrm{m} / \mathrm{h}$, for a current density of $10 \mathrm{~mA} / \mathrm{cm}^{2}$. The minimal deposit time has been set to $7 \mathrm{~h}$. This deposit time achieves a microposts growth with a height larger than the thickness of the Riston PM275, and so allows then for a polishing and/or grinding step of the microposts in order to obtain a plane surface and ensure a good electrical and thermal contact between the microposts and the DBC substrate. A mechanical polishing is realized thanks to a cloth polishing disk and a diamond liquid with grains of $9 \mu \mathrm{m}$ down to $1 \mu \mathrm{m}$ in the laboratory-scale experiment. Thinner grains are available to improve further the state of surface. Fig. 3 shows the microposts for a deposit time of $8 \mathrm{~h}$ before and after the polishing step. The height of the microposts is, respectively, 96 and $62 \mu \mathrm{m}$ before and after the polishing step. This step is essential to obtain a fixed final thickness of the die in case of multi-dice modules with dice of different initial thickness. A quite good tolerance is achievable with a grinding/polishing step (namely in the $100 \mathrm{~nm}$ range and better). This avoids the use of intercalars that multiply the interfaces if not increase the number of solder interfaces [12].

A diode die with its polished microposts is attached by $\mathrm{Cu} / \mathrm{Sn}$ TLP bonding to the DBC substrate. A thin tin layer (thickness less than $1 \mu \mathrm{m}$ ) is deposited on the microposts and the DBC substrate. The tin thickness and bonding temperature are deduced from the $\mathrm{Cu} / \mathrm{Sn}$ phase diagram in order to obtain a $\mathrm{Cu}$-rich/Sn
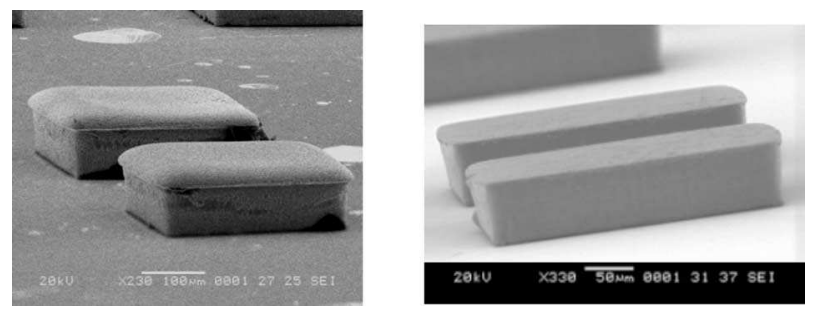

Fig. 3. SEM images of the microposts for a deposit time of $8 \mathrm{~h}$ before (a) and after (b) the grinding/polishing step.

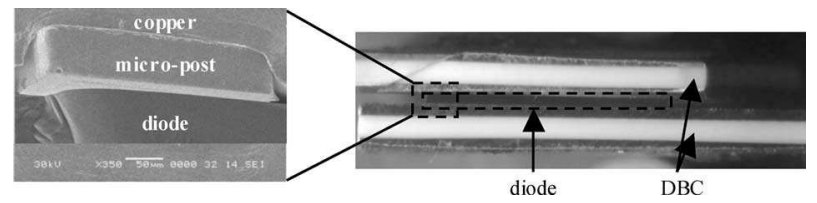

Fig. 4. Diode interconnected concurrently to top and bottom DBC.

joint. Fig. 4 presents a $3.5 \mathrm{kV}-100$ A diode with microposts on anode side and bonded concurrently to a top and bottom DBC through $\mathrm{Cu} / \mathrm{Sn}$ TLP proposal. A tin thickness of $0,5 \mu \mathrm{m}$, a pressure of $10 \mathrm{MPa}$ and a temperature of $300^{\circ} \mathrm{C}$ during $7 \mathrm{~min}$ have been considered. A SEM image of the $\mathrm{Cu} / \mathrm{Sn}$ joint between a microposts and a DBC is shown in Fig. 5. As a demonstration of a $3.5 \mathrm{kV}-100$ A diode integrity after interconnection process, the direct electrical characteristic is pictured in Fig. 6. This characteristic is identical to the manufacturer datasheet [13].

\section{DISCUSSION}

The previous sections cover the details of a first experiment of a proposed interconnection technique to avoid wire bond and solder. So far only the feasibility of the technique has been demonstrated since many issues are under investigation: influence of micropost dimensions with regard to die pad dimension and positioning, parameters of electroplating growth 


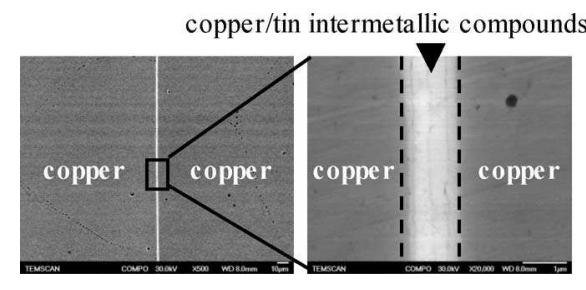

Fig. 5. SEM image of a $\mathrm{Cu} / \mathrm{Sn}$ joint between a microposts and a DBC.

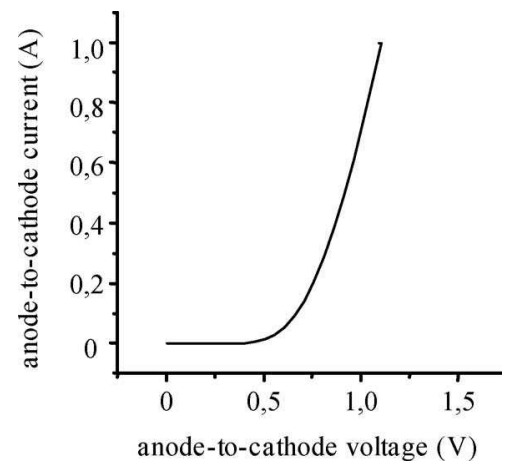

Fig. 6. Direct electrical characteristic of a $3.5 \mathrm{kV}-100$ A diode with the microposts interconnection.

TABLE II

COMParison of ACtual PaCKaging TeChNOLOgIES With the Microposts INTERCONNECTION

\begin{tabular}{|c|c|c|c|}
\hline $\begin{array}{c}\text { Interconnection } \\
\text { technology }\end{array}$ & $\begin{array}{c}\text { Parasitic } \\
\text { inductance }\end{array}$ & $\begin{array}{c}\text { Thermal } \\
\text { management }\end{array}$ & $\begin{array}{c}\text { Height compensation } \\
\text { of dice with shims }\end{array}$ \\
\hline $\begin{array}{c}\text { Wire } \\
\text { bonding }\end{array}$ & high & $\begin{array}{c}\text { one-sided } \\
\text { cooling }\end{array}$ & no \\
\hline $\begin{array}{c}\text { Solder } \\
\text { interconnection }\end{array}$ & low & $\begin{array}{c}\text { double-sided } \\
\text { cooling }\end{array}$ & $\begin{array}{c}\text { yes } \\
\text { no (flip chip on flex } \\
\text { technology [3]) }\end{array}$ \\
\hline $\begin{array}{c}\text { Interconnection } \\
\text { by springs }\end{array}$ & low & $\begin{array}{c}\text { one-sided } \\
\text { cooling }\end{array}$ & no \\
\hline Pressure contact & low & $\begin{array}{c}\text { double-sided } \\
\text { cooling }\end{array}$ & $\begin{array}{c}\text { yes } \\
\text { no (3D press-pack } \\
\text { technology [5]) }\end{array}$ \\
\hline $\begin{array}{c}\text { Interconnection } \\
\text { by electroplated } \\
\text { metallizations }\end{array}$ & low & $\begin{array}{c}\text { double-sided } \\
\text { cooling }\end{array}$ & $\begin{array}{c}\text { yes (embedded power } \\
\text { technology [12]) } \\
\text { no (power overlay } \\
\text { technology [14]) }\end{array}$ \\
\hline $\begin{array}{c}\text { Micro-posts } \\
\text { interconnection }\end{array}$ & low & $\begin{array}{c}\text { double-sided } \\
\text { cooling }\end{array}$ & \multicolumn{2}{c}{ no } \\
\hline
\end{tabular}

rate, tolerance of grinding/polishing step, optimal parameters of $\mathrm{Cu} / \mathrm{Sn}$ TLP bonding, thermal performance measurement of assembly, intrinsic reliability analysis, interconnection parasitic components measurement and reliability of a multidice assembly. Probably the optimal parameters of TLP-bonding depend on the industrial setup. However, the copper intermetallic interface is under analysis to relate the shear force capability to the metallurgical composition. The dimensions of the microposts have a significant influence on the thermal performance of the assembly and the parasitic components. The latter components make sense with respect to commutation what implies to realize a two-dice assembly (a diode and a MOSFET, for example). The accuracy of the grinding/polishing step is then of primary importance. So, a complete experiment plan is required and under development. Table II presents a comparison of actual packaging technologies to situate the micro-posts interconnection.

\section{CONCLUSION}

This letter has presented an alternative interconnection solution for power semiconductor dice that wishes to be compatible with 3-D integration of power modules. The different steps (electroplating and assembly by $\mathrm{Cu} / \mathrm{Sn}$ TLP bonding) have been described. A first demonstrator on diode dice proves the feasibility of the proposal as the electrical characterization shows that the diode has kept its integrity and a satisfying electrical connection is obtained. Near future work focuses the production of a switching-cell (diode/MOSFET) for electrical transient characterizations and thermomechanical analysis. Moreover, electromagnetic and thermal simulations of the microposts interconnection will then be validated.

\section{REFERENCES}

[1] K. Xing, F.-C. Lee, and D. Borojevic, "Extraction of parasitics within wire bond IGBT modules," in Proc. IEEE Appl. Power Electron. Conf. Expo., Feb. 1998, pp. 497-503.

[2] M. Ciappa, "Selected failure mechanisms of modern power modules," Microelectron. Rel., vol. 42, no. 4, pp. 653-667, Apr. 2002.

[3] J.-N. Catala, J.-G. Bai, X. Liu, S. Wen, and G.-Q. Lu, "Three dimensional packaging for power semiconductor devices and modules," IEEE Trans. Adv. Packag., vol. 28, no. 3, pp. 404-412, Aug. 2005.

[4] X. He, X. Zeng, X. Yang, and Z. Wang, "A hybrid integrated power electronic module based on pressure contact technology," in Proc. IEEE Power Electron. Spec. Conf., Jun. 2006, pp. 1-5.

[5] E. Vagnon, J.-C. Crébier, Y. Avenas, and P.-O. Jeannin, "Study and realization of a low force 3D press-pack power module," IEEE Power Electron. Spec. Conf., Jul. 2008, pp. 1048-1053.

[6] J.-G. Bai, J.-N. Catala, and G.-Q. Lu, "Comparative thermal and thermomechanical analyses of solder bump and direct solder bonded power device packages having double sided cooling capability," in Proc. IEEE Appl. Power Electron. Conf. Expo., Feb. 2004, vol. 1, pp. 1240-1246.

[7] L.-H. Zhang, X. Yang, F. Wang, and Z.-A. Wang, "Pressure contact packaging for hybrid electric vehicle drive," in Proc. IEEE Power Electron. Spec. Conf., Jun. 2007, pp. 2228-2233.

[8] M. Mermet-Guyennet, "New structure of power integrated module," in Proc. Int. Conf. Integr. Power Syst., Jun. 2006, pp. 133-138.

[9] U. Scheuermann and F. Ebersberger, "Packaging of large area power chips-Extending the limits of standard module technology," [Online]. Available: http://www.semikron.com

[10] W. Welch, J. Chae, and K. Najafi, "Transfer of metal MEMS packages using a wafer-level solder transfer technique," IEEE Trans. Adv. Packag., vol. 28 , no. 4, pp. 643-649, Nov. 2005.

[11] Dupont. (2006). "Datasheet Dupont Platemaster PM200," [Online]. Available: http://www2.dupont.com.

[12] Z. Liang, J.-D. V. Wyk, F.-C. Lee, D. Borojevic, E.-P. Scott, Z. Chen, and Y. Pang, "Integrated packaging of a $1 \mathrm{~kW}$ switching module using a novel planar integration technology," IEEE Trans. Power Electron., vol. 19, no. 1, pp. 242-250, Jan. 2004.

[13] "Datasheet of SIDC185D350A6 diode," Infineon, [Online]. Available: http://www.infineon.com.

[14] R. Fillion, E. Delgado, P. McConnelee, and R. Beaupre, "A high performance polymer thin film power electronics packaging technology," in Proc. Adv. Microelectron., Sep. 2003, pp. 7-13. 